\title{
6. INMATES IN HIGHER EDUCATION IN ITALY AND SPAIN
}

\author{
Legal, Cultural and Technological Issues in a Complex \\ Network of Continuity and Discontinuity
}

\section{INTRODUCTION}

Inmates who attend university may be considered non-traditional students, presenting one or more of the features that are usually attributed to this definition: break between high school and university, full time job, part-time attendance at university, independent financial situation, presence of children or dependants other than their own partner, being a single parent, attaining only a GED (not a high school diploma). ${ }^{1}$ Moreover, for all the students in prison, each stage of the training process (choice, enrolment, didactics, individual study) is strongly influenced and limited by the space in which they are incarcerated. The physical, socio-cultural and professional discontinuity induced by the environment and its rules (official, unofficial, explicit and implicit) determine for all the imprisoned people a marginal condition that, beyond the different orientations of the criminal law, was and continues to be a summary of the prison sentence, where the wall - the fundamental instrument of containment and control - is not only its symbol but also its deeper raison d'être.

Nevertheless, according to the correctional paradigm (endorsed by the international rules and adopted, at least on paper, by a wide range of nations), the penalty should not only punish (retributive function) but also rehabilitate the convicts. In this design the prison, still the main recourse for penalising offenders, ${ }^{2}$ should operate as a positive discontinuity of life-style and opportunities (principally learning and working) to target changes in convicts' judgements, values and behaviours, providing them with the motivation to make a definitive switch from a criminal route to that of integration into a law-abiding society. However, too often prison still represents a place of negative discontinuity, where the physical isolation and the consequent social deprivation are accompanied by a lack of opportunities, resulting in further marginalisation and in attacks (sometimes systemic) on human dignity, unfortunately more frequent than the cases confirmed by the courts of national and international justice. 
Confronted with this scenario, why focus specifically on detainees in higher education, who represent a small minority of students in prison and a very limited crosssection of inmates overall? Academic study behind bars deserves to be encouraged and supported because not only does it involve an increasing number of prisoners, but it also has a particular significance: as we will see for the two considered countries. University can offer the opportunity of transformation not only of the convict but of the prison itself, in terms of its human, cultural and physical environment.

Even if education, up to its higher levels, is often sanctioned as an inalienable human right, a series of obstacles (legislative, organisational, cultural, technical) de facto restrict full access of prisoners to the higher grades of education, especially with regard to university. These threaten both the continuity of the learning career for students that want to continue their academic pursuits after a custodial sentence or while in custody, as well as the choice, in positive discontinuity, of beginning a course during the period of incarceration.

As a result in this context, both the concepts of continuity and discontinuity can be meant in a positive or negative way according to whether they might produce empowerment or marginalisation, and consequently they appear interwoven in a complex relationship, complementary yet at the same time circular. ${ }^{3}$

This short comparative research focuses on Italy and Spain: these two major Euro-Mediterranean countries have common roots and a lot of cultural similarities; furthermore, they are comparable in the dimensions and the general structures of their penal systems but they present remarkable differences in the management and the outcomes of academic education in prison (Table 1, Figures 1-2).

Through a lecture in three dimensions - legislative, cultural and technological the study aims, on the one hand, to identify and analyse the adopted models, checking if they comply with international agreements, especially at the continental level; while on the other hand, to compare the main outcomes, highlighting the best and most replicable practices.

Table 1. University students in prison during 2009 in Italy and Spain, by gender and nationality

\begin{tabular}{|c|c|c|c|c|c|c|c|c|}
\hline \multirow[t]{2}{*}{ Countries } & \multicolumn{6}{|l|}{ Gender } & \multicolumn{2}{|c|}{ Foreigners } \\
\hline & $\begin{array}{l}\text { F univ. } \\
\text { students }\end{array}$ & $\begin{array}{l}\text { M univ. } \\
\text { students }\end{array}$ & Tot. & $\begin{array}{l}F \\
\text { inmates }\end{array}$ & $\begin{array}{l}M \\
\text { inmates }\end{array}$ & Tot. & $\begin{array}{l}\text { Overall } \\
\text { univ. } \\
\text { students }\end{array}$ & $\begin{array}{l}\text { Overall } \\
\text { tot. } \\
\text { inmates }\end{array}$ \\
\hline $\begin{array}{l}\text { Italy } \\
(31 / 12 / 09)\end{array}$ & $\begin{array}{l}79 \\
(26 \%)\end{array}$ & $\begin{array}{l}224 \\
(74 \%)\end{array}$ & 303 & $\begin{array}{l}2751 \\
(4 \%)\end{array}$ & $\begin{array}{l}62040 \\
(96 \%)\end{array}$ & 64791 & $13 \%$ & $\begin{array}{l}24067 \\
(37 \%)\end{array}$ \\
\hline $\begin{array}{l}\text { Spain } \\
(31 / 10 / 09)\end{array}$ & $\begin{array}{l}128 \\
(11 \%)\end{array}$ & $\begin{array}{l}1065 \\
(89 \%)\end{array}$ & 1193 & $\begin{array}{l}6076 \\
(8 \%)\end{array}$ & $\begin{array}{l}70003 \\
(92 \%)\end{array}$ & 76079 & $35 \%$ & $\begin{array}{l}27162 \\
(35 \%)\end{array}$ \\
\hline
\end{tabular}

Sources: www.giustizia.it, Viedma Rojas (2013 for students in Spain, Ministerio del Interior (2013) for total in Spain 


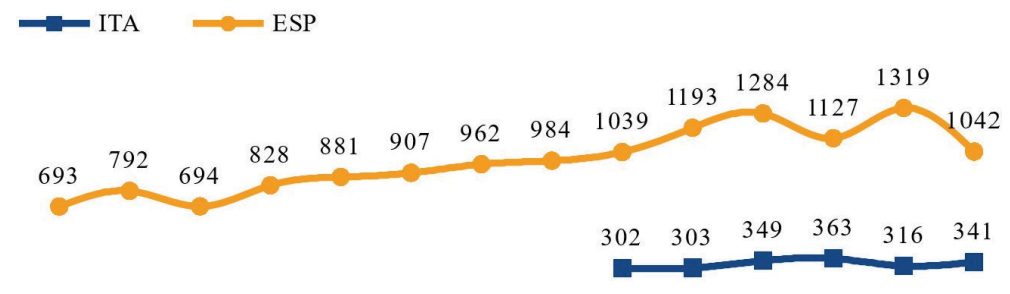

20002001200220032004200520062007200820092010201120122013

Figure 1. Yearly results of jailed university students in Italy (2013) and Spain (2000-2013).

Sources: www.giustizia.it for Italy; Viedma Rojas, 2013 for Spain

- ITA ESP

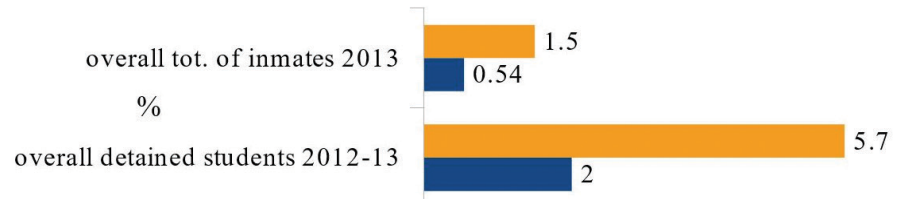

Figure 2. Percentage of jailed university students in Italy and Spain (2013) overall the total prison population (respectively 62536 and 66765) and overall the total number of students in jail (respectively 16836 and 18385).

Sources: www.giustizia.it for Italy; SGIP (2014) for Spain. Note: the Italian data relates to December the 31st while the Spanish data relates to October 31st each year

\section{PRISON EDUCATION AND UNIVERSITY: NOTES OF INTERNATIONAL LAW}

In 1955 the United Nations (UN) adopted the Standard Minimum Rules for the Treatment of Prisoners, that sanctioned, for the first time on a global level, the contrarieties to penal treatment that are prejudicial to human rights and dignity. They were inspired by the principle of accountability of the condemned (free and conscious participation in treatment) in preparation for their return to the outside world as an active force. Furthermore, the UN Rules identified in education the principal vehicle for the development of the person as a whole, through a project that takes into account their social and cultural background (arts. 65, 77, 78).

The Council of Europe welcomed the UN resolution, integrating it in a text known under the title of European Prison Rules (EPR). Issued for the first time in 1973 ( $\mathrm{R}$ [73] 5), then updated in 1987 (R [87] 3) and in 2006 (R [06] 2), they cover all aspects of everyday life of the inmates, as well as various questions concerning the prison staff. Their programmatic nature and the progressive reception of previous recommendations made the EPR the main source of Continental law in this field.

On the question of education in prison, the EPR (arts. 77-82 in the ' 73 and ' 87 editions, art. 28 in the 2006 edition) essentially echo the approach of the UN Rules. 
Although the EPR, as well as the UN Rules, never mention explicitly the university, we will highlight a few points most involved with the academic study, referring to the last edition of the text (2006).

1. Par. 4 of art. 28 encourages full parity of education with work, even from the point of view of pay, so preventing the economic penalty arising from the choice of studying instead of working. This is particularly relevant with regards to higher education, which can absorb a considerable part of the day and proves difficult to reconcile with a job.

2. Par. 7 of art. 28 draws attention to the need to integrate prison education into the public system of education and vocational training, following two policies: on the one hand, making compatible the learning programmes both in and out of prison, so as to promote continuity after release; on the other hand, allowing prisoners to attend external courses, whenever possible.

3. Finally, pars. 5 and 6 of art. 28 recommend that each prison make available to all convicts a comprehensive library ('adequately stocked with a wide range of both recreational and education' "in co-operation with community library services'.

The specific theme of the university had not been addressed directly even in 1989, in the 17 points which made up the Recommendation on education in prison ( $R$ [89] 12), which, however, was issued together with an explanatory memorandum. This analytical report, compiled by a committee of experts, observes the prison education systems of the member countries according to two circuits: external and internal to prisons. This time the university is mentioned in both paths: in one case, briefly, to promote once again the integration with the public education system outside the prison; in the other case, more extensively, to analyse and recommend opportunities and best practices across European prisons, with a strong focus on distance learning (traditional and electronic), as well as on access to MOOCs (Massive Open Online Courses), which are offered by many universities at the present time, with even more institutions expected to adopt this method over the coming years.

\section{UNIVERSITY STUDY IN PRISON: FRAMEWORKS IN ITALY AND SPAIN}

Both the Italian (1948) and Spanish (1978) Constitutions affirm the right-duty to compulsory education (respectively arts. 33-34 and art. 27) and the former adds constitutional protection of access to higher education for the deserving underprivileged (art. 34 pars. 3-4). In addition, both provide new ethical foundations to penalty, prescribing non-afflictive methods and rehabilitative aims (respectively art. 27 par. 3 and art. 25 par. 2), even if, naturally, they are silent about the contents of the penalty, a field left open to the legislator, but still characterised - more so in Italy than in Spain - by prison sentences. Therefore, we will examine the laws in force in the two countries, trying to evaluate how, and to what extent, they have taken action to encourage academic study among detainees, focusing particularly on the three issues raised in the European context. 


\section{The Laws and the Actors in Italy}

The Italian L. n. 354/1975 (henceforward OP: Ordinamento Penitenziario) embodies, and in some ways anticipates, the principles that were successful at the international level: humanity and dignity of the conditions of detention; rehabilitative purpose of the treatment; permeability of the prison, both involving the civil society in intramural activities (art. 17), as well as fostering inmates' contacts with the outside (arts. 18, 21, 28, 30). These external contacts were raised to a real pedagogical tool for the re-educational treatment (art. 15), together with work (art. 20), religion (art. 26) and the participation in cultural, recreational and sports activities (art. 27). The penitentiary institution is called upon to ensure the provision of appropriate equipment and environments (art. 12 par. 1), including the obligation to set up a library (with books and magazines), managed with the participation of the prisoners themselves (art. 12 pars. 2-3).

Education, understood as cultural and professional training (art. 19), has a prominent role: recalling that the obligation to establish courses of primary education and literacy was already provided for by L. n. 535/1958, the OP pays special attention to the secondary school and to higher education. In fact, par. 4 of art. 19 states that 'the attainment of university courses and equivalent must be fostered and the attendance at school courses by correspondence, radio and television must be favoured'.

The first Implementing Regulation of the OP (D.P.R. n. 431/1976) clarified that access to university is a right of all prisoners, both in execution of sentence and in custody. It provided that there were 'established the appropriate agreements with academic authorities to enable students to receive every possible help and to take the examinations' (art. 42). As can be noticed, the emerging pattern reflects the local autonomy model, but not without granting a national framework of incentives: the possibility of exemption from work 'in view of commitment and proved profit' (art. 42), the financial support for deserving students or economically disadvantaged (as reimbursement for fees and books) and an award for academic performance (art. 43).

Nevertheless, this first Regulation was silent on the concrete logistics (necessary complement to the theoretical affirmation of a right), thus severely limiting the access to higher education, providing no facilitation for the entry of university teachers and leaving the designation of educational spaces within the discretion of the management of prisons. In addition, university students could not take the exams or, even less, attend lessons in their respective faculties, since the permission to leave the prison was granted to inmates only for exceptional and grave circumstances (art. 30 of the OP). The amendment to par. 2 of art. 30 of the OP, by L. n. 450/1977, oriented the Judiciary Supervisory towards a wide interpretation of the rule while continuing to exclude the study-related reasons. Only after ten years (by L. n. 663/1986, that added the art. 30 ter to the OP), will the new permission-prize accord a momentary departure from the penitentiary in order, among other things, to cultivate cultural interests and study, this way allowing the convicted university students to take the examinations in a regular session. ${ }^{4}$ 
The new Implementing Regulation of the OP (D.P.R. n. 230/2000) introduced a number of significant changes on this issue: it states that the university students, as far as possible, are located 'in cells and wards adapted to study, also making available appropriate common rooms for them' and it provides permission to 'keep, in their cells and in other rooms, study books, publications and all the learning tools necessary in their study', including "computers, tape players and portable compact disc" (art. 44). Essentially, the Italian lawmaker finally recognised the important role played in the higher education field by learning and research tools on the one hand and, on the other, by environments suited to cooperation and confrontation (between student and teacher, as well as among learners). ${ }^{5}$

On the basis of the provisions of art. 44 of the new Implementing Regulation, since the early 2000s, numerous cooperation agreements between universities and prisons have been signed (Table 2), although the origin of the Prison University Poles (PUPs) is situated, as often happens, not in a law but in a spontaneous practice, in this case deeply marked by the contribution of voluntary work. ${ }^{6}$ The PUPs, distributed fairly evenly throughout the country, usually guarantee the placement of the university students in

Table 2. The penitentiary university poles in Italy (1998-2015)

\begin{tabular}{|c|c|c|c|c|}
\hline Denomination & Year & Involved prisons & Participating Universities & E-learn \\
\hline PUP of Turin & 1998 & $\begin{array}{l}\mathrm{CC} \text { (Casa Circondariale: } \\
\text { remand centre) of Turin }\end{array}$ & Università di Torino & \\
\hline PUP of Tuscany & $\begin{array}{l}2000 \\
2003 \\
2010\end{array}$ & Prisons in Tuscany & $\begin{array}{l}\text { Università di Firenze/ } \\
\text { Università di Pisa/ } \\
\text { Università di Siena }\end{array}$ & \\
\hline PUP of Bologna & $\begin{array}{l}2000 \\
2013\end{array}$ & CC di Bologna & Università di Bologna & $X$ \\
\hline $\begin{array}{l}\text { PUP of Alessandria S. } \\
\text { Michele/Pausania }\end{array}$ & $\begin{array}{l}2001 \\
2008\end{array}$ & $\begin{array}{l}\text { CR (Casa di Reclusione: } \\
\text { prison for sentence } \\
\text { execution) of Alessandria }\end{array}$ & $\begin{array}{l}\text { Università del Piemonte } \\
\text { orientale A. Avogadro }\end{array}$ & $X$ \\
\hline $\begin{array}{l}\text { SUP (University Prison } \\
\text { System) of Lazio }\end{array}$ & $\begin{array}{l}2003 \\
2008 \\
2009\end{array}$ & Prisons in Lazio & $\begin{array}{l}\text { Università della Tuscia, } \\
\text { Università di Cassino, } \\
\text { Università La Sapienza, } \\
\text { Università di Tor Vergata, } \\
\text { Università di Roma Tre }\end{array}$ & $\mathrm{X}$ \\
\hline PUP of Triveneto & 2003 & CR of Padova & Università di Padova & \\
\hline $\begin{array}{l}\text { Memorandum } \\
\text { of undertaking } \\
\text { DAP (Department } \\
\text { of Penitentiary } \\
\text { Administration) - } \\
\text { University of Catania }\end{array}$ & 2003 & $\mathrm{CC}$ of Caltagirone & Università di Catania & $\mathrm{X}$ \\
\hline
\end{tabular}




\begin{tabular}{|c|c|c|c|c|}
\hline Denomination & Year & Involved prisons & Participating Universities & E-learn \\
\hline PUP of Calabria & 2004 & $\mathrm{CC}$ of Catanzaro & $\begin{array}{l}\text { Università Magna Grecia } \\
\text { di Catanzaro }\end{array}$ & \\
\hline PUP of Lecce & 2004 & CC of Lecce & Università di Lecce & \\
\hline PUP of Sardegna & $\begin{array}{l}2004 \\
2007 \\
2014\end{array}$ & $\begin{array}{l}\mathrm{CC} \text { of Sassari/CC of } \\
\text { Alghero/Prisons in } \\
\text { Sardinia }\end{array}$ & Università di Sassari & \\
\hline PUP of Abruzzo & 2005 & $\begin{array}{l}\text { Prisons in Abruzzo and } \\
\text { Molise }\end{array}$ & $\begin{array}{l}\text { Università telematica } \\
\text { L. da Vinci di Chieti }\end{array}$ & $\mathrm{X}$ \\
\hline PUP of Reggio Emilia & 2005 & $\mathrm{CC}$ of Reggio Emilia & $\begin{array}{l}\text { Università di Modena e } \\
\text { Reggio Emilia }\end{array}$ & $\mathrm{X}$ \\
\hline PUP of Brescia Verziano & 2006 & CR of Brescia Verziano & Università di Brescia & \\
\hline PUP of Sulmona & 2006 & CR of Sulmona & Università dell'Aquila & \\
\hline $\begin{array}{l}\text { E-le@rning in carcere } \\
\text { (proj.) })^{7} / \mathrm{PUP} \text { della } \\
\text { Campania }\end{array}$ & $\begin{array}{l}2008 \\
2013\end{array}$ & $\begin{array}{l}\text { CR-ICATT of Eboli/ } \\
\text { Prisons in Campania }\end{array}$ & $\begin{array}{l}\text { Università di Salerno/ } \\
\text { Università Federico II } \\
\text { di Napoli }\end{array}$ & $\mathrm{X}$ \\
\hline $\begin{array}{l}\text { Memorandum of } \\
\text { undertaking DAP - } \\
\text { University of Palermo }\end{array}$ & 2009 & CC Pagliarelli & Università di Palermo & \\
\hline $\begin{array}{l}\text { Metropolitan PUP of } \\
\text { Milan }\end{array}$ & 2013 & $\begin{array}{l}\text { Prisons in province of } \\
\text { Milan }\end{array}$ & $\begin{array}{l}\text { Università Bicocca di } \\
\text { Milano }\end{array}$ & \\
\hline PUP of Teramo & 2014 & $\mathrm{CC}$ of Teramo & Università di Teramo & \\
\hline PUP of Ferrara & 2014 & $\mathrm{CC}$ of Ferrara & Università di Ferrara & \\
\hline PUP of Umbria & 2015 & Prisons in Umbria & Università di Perugia & \\
\hline
\end{tabular}

Sources: Palmisano (2015); Pastore (2015); www.giustizia.it; www.ristretti.it

a special ward, supplied with individual cells, equipped with a common study room and subjected to a softer discipline. Universities, for their part, provide a range of services: the teaching (by mail, Internet or in presence, for students on probation); the examination boards (online and/or in presence, in prison and/or at the university); a certain amount (highly variable) of tutors, online and/or in presence, allowed access to the prisons (Pillera \& González Monteagudo, 2016); additional economic benefits, provided for disadvantaged students or specifically agreed for inmates.

\section{The Laws and the Actors in Spain}

Spain, free of the Franco regime, rapidly produced a modern democratic legislation, approving, one year after the Constitution, its Penitentiary Act. Like the Italian one, the L.O. n. 1/1979 (henceforth LOGP: Ley Orgánica General Penitenciaria) is also based on the sources of international law and it is geared to the rehabilitation 
and social reintegration of the condemned (art. 1). Also in Spain the law allocates, jointly with work (considered as a right-duty), a key role to education and training (respectively: the 2nd chapter, arts. 26-35; and the 10th chapter, arts. 55-58): the obligation to establish a library in each prison is in force (art. 57) ${ }^{8}$ along with the duty to provide school courses as similar as possible to those attended by students outside the prison (art. 55 par. 2); moreover, the principle of integration with the public system is implemented for the acknowledgement of qualifications and certifications (art. 56 par. 1). Finally, study is encouraged, allowing access to facilities to follow the related activities, both outside the institution, and, when this is not possible, inside the prison, by correspondence, radio and television (art. 55 par. 3).

The first Implementing Regulation (R.D. n. 1201/1981) decreed that university students have the right to communicate with their own teachers for study purposes and for the examinations (art. 168). Almost twenty years later, the second Regulation (R.D. n. 190/1996) adds at least two relevant details about university education: (a) special modifications to the penitentiary regime, due to the participation in educational programmes, can be obtained by inmates (art. 124 par. 3); (b) the possibility to keep in their cell, solely for educational or cultural purposes, personal computers without network connection and subjected to periodic inspections of the hard disk (art. 129).

Overall, the organisational model provided was not unlike the Italian one: although with vague directions, it allowed the free collaboration between prisons and universities. However, the developments and the results were significantly different compared to Italy, because the historical-cultural context where the phenomenon had its origin was very different. In Spain the conditions for university study in prison have ripened as a result of a broad movement against Franco in the late 60's (when Italy had been a democratic country for more than 10 years), in which university students played an active role. Indeed, in 1970, about 200 of them tasted political prison (Viedma Rojas, 2013). In spite of this, they continued to study, supported by the respective universities, and their choice became another form of opposition to the dictatorship. Until today, 'although nuanced and transformed, this spirit of resistance continues to form part of the interpretation of the action' (Viedma Rojas, 2013, p. 106), that can be read as a research of continuity and normality in the discontinuity represented by the experience of being imprisoned.

Indeed, in the early years of the Spanish transition, university study in prison vanished but, relatively quickly, at the end of the 70's it appeared again, among common inmates and especially among those from armed separatist movements (ETA, GRAPO, FRAP). Similarly, in Italy, in the same period but on a reduced scale, those condemned for terrorism were among the first convicts to take a degree (Migliori, 2004, p. 28).

In 1983, the first Spanish socialist government came to power and promoted an agreement between UNED (Universidad Nacional de Educación a Distancia), Ministry of Education, Ministry of Justice and Prison Administration, but this did not prevent the latter from signing several other agreements at the local level and thus 
involving various universities. The policy implemented by the socialists, marked by a cultural dynamisation of the prisons, allowed an extremely rapid increase in the number of university students among the imprisoned people (Viedma Rojas, 2013).

In the following years this number continued to increase, as, on the one hand, the role of UNED became consolidated, ${ }^{9}$ while on the other, the contribution of the University of País Vasco (UPV) rapidly emerged and, in the late 90's, reached a student population among inmates close to that of UNED (Viedma Rojas, 2013). Unlike the latter, however, UPV always refused to sign any agreements with the Prison Administration (developing its work through the UNED Centre of Bergara); moreover, a great percentage of its imprisoned students were composed of members of the Basque separatist organisation, ETA. These elements sparked an interinstitutional conflict that brought about the legal expulsion of UPV from prisons in 2003, as a result of the amendment to art. 56 of LOGP, operated by L.O. n. 6/2003. ${ }^{10}$ A second paragraph was added to the said article, specifying that: (a) the prison administration must sign the necessary agreements with the universities, ensuring conditions, rigour and quality appropriate to this type of study as well as the use of a methodology adapted to the prison context; (b) such agreements have to be established preferably with UNED, preserving, however, the possibility of accepting partnerships with other universities, in compliance with the previous rules. ${ }^{11}$

Consequently, a specialistic and centralised model was developed, managed entirely by UNED, in which, from the a.y. (academic year) 2003-2004, no public university took part or expressed interest in doing so, except UPV (Viedma Rojas, 2013). Of course, this chosen path reduces the diversification both in the curriculum and in the teaching methods. Nevertheless, UNED grants coverage throughout the country, thanks to its specialisation in distance learning as well as to the local support of its Centros Asociados, so enjoying rootedness and social legitimacy. Therefore, the Spanish model allows: the protection of the right of access to university, even with high spatial dispersion of the students; the extension of the provision to a wide variety of degree programmes, proposed with a flexible (andragogic and specific to prison) methodology; the guarantee of greater control and safety, as UNED shares with the prison system a direct dependence on the Central State Administration.

\section{ICT FOR ACADEMIC STUDY IN ITALIAN AND SPANISH PRISONS}

ICT has brought new tools for inclusive and active learning, particularly relevant to the contexts of isolation (geographical, physical, social or cultural), but the use of computers, and in particular the use of the internet, is heavily restricted in European prisons, when not totally forbidden, due to legal, practical and cultural problems. In spite of this, these technologies, used to support (to implement or to integrate) the treatment of prisoners, appear to represent a viable and increasingly practised methodological solution, especially in the UK, Scandinavia, Central Europe and Spain (Pillera, 2015). In Italy, e-learning has been used successfully, among others, in vocational training projects Trio (in Tuscany) and CISCO (at the CR of Bollate), 
as well as in the @URORA project, aimed at juvenile prisons (Suriano, 2011; Diana, 2013).

Furthermore, the use of e-learning in university education for prisoners is now documented in most of Europe, in the Anglo-Saxon world outside Europe and in South America (Costelloe et al., 2012; Hawley et al., 2013; Champion \& Edgar, 2013; Czerwinski et al., 2014). This is due to the power and flexibility of ICT in education, in terms of the inherent characteristics of the new media (hypertext, multimedia, simulation, augmented reality, ubiquity), in strictly educational terms (individualisation of teaching, customisation of times, places and instruments, opportunities for remote cooperative learning, possibility to monitor the processes), and also in organisational and financial terms (flexibility, modularity, scalability, re-usability of the learning objects). In addition, e-learning appears effective in promoting continuity of an academic career for those entering or leaving prison.

As regards Italy, in Table 2 we have already indicated the PUPs in which there are e-learning resources for students ( 7 of 20). ${ }^{12}$ In the hope and expectation that many more Italian universities develop structures and know-how related to de-materialised teaching and fulfil their third mission also entwining appropriate partnerships with (more or less distant) prisons, we would like to highlight the experience of the SUP (Sistema Universitario Penitenziario: University Penitentiary System) that was developed in Lazio using leading technologies and that had been proven effective as an organisational system. As elsewhere, the model adopted in Lazio is orchestrated on a regional basis but it appears extremely widespread in the territory. It consists of an institutional network that involves the PRAP (Provveditorato Regionale dell'Amministrazione Penitenziaria: Regional Superintendency of Penitentiary Administration); the 14 prisons in the region; the three Roman universities and those of Tuscia and Cassino; LazioDiSU (the regional institute for the provision of academic education); regional institutions and the regional Guarantor of detained persons, whose involvement in the project includes mediating in the management of paperwork and providing free textbooks and teaching materials (Garante, 2013).

As part of the experience of the SUP Lazio, the project "Teledidattica - Università in carcere", created in 2006 and designated as using best practices by the Ministry of Justice, consists of an operating agreement between the CC Rebibbia NC, the University of Tor Vergata, LazioDiSU and the telecommunications company Fastweb, with the coordination of the Guarantor (Garante, 2013). It makes available, within the Roman prison, three whole degree programmes (Humanities, Law, Economics), that currently account for about 40 of the 113 university students involved in the SUP (http://web.uniroma2.it). The lessons are progressively videotaped in their natural setting (using special lecture halls at University of Tor Vergata) and then uploaded onto a platform, that is accessible from two specifically equipped classrooms inside the prison of Rebibbia NC. Here the students can use computers, projectors, a multimedia library and a teleconferencing system, that is dedicated to the online tutoring and to examinations. The first is guaranteed, at least monthly, even in presence, by means of disciplinary tutors who have access to the 
prison; the second can be taken in presence (with the commission that goes to the prison or, vice versa, through the granting of a permit) or, when it is necessary for security reasons, directly online (through a conference call but with the presence in jail of a member of the examination board). ${ }^{13}$

In Spain, despite many universities offering degree courses or Masters' online for several years, UNED, as we saw earlier, is currently the only entity authorised to provide university education to the inmates, who are distributed throughout approximately 90 prisons (Viedma Rojas, 2013). The PEUCP (Programas de Estudios Universitarios en Centros Penitenciarios: University Study Programmes in Penitentiary Centres) of UNED offers to convicts: information, orientation and enrolment services; in some prisons, exam simulations for access to Curso de Acceso Directo (Direct Access Course), reserved for people over 25 years old; support in the use of the e-learning platform aLF (www.innova.uned.es/servicios/alf); assistance from the closer Centro Asociado UNED, for students serving sentences in the open prison system $(C I S)^{14}$ or on probation or on parole (http://portal.uned.es). Research has found several similarities between the main sociological variables recorded for jailed students and for the rest of the students at UNED, in particular with regard to the distribution by age (Bardisa Ruiz et al., 2003). Furthermore, the favourite degree programmes in the Spanish prison are practically the same as the rest of the UNED students but they coincide only partially with the preferred subjects among Italian inmates (Table 3 ), where we can notice a stronger (but diminishing) concentration of choices, probably due to the more limited degrees offered in Italian PUPs.

With the increasing use of ICT, the methodology of UNED has also evolved, first in the direction of the digitisation of contents, then towards their de-materialisation and delivery across the internet. However, these innovations have been adopted much more slowly in prisons (Callejo \& Ramón Bautista, 2003): now ALF also services inmates for UNED's entire learning offer (only some degree courses that require laboratory practice are excluded from PEUCP), but not all prisons are yet equipped

Table 3. Six subject areas most selected by Italian and Spanish inmates studying on university programs

\begin{tabular}{lllll}
\hline Spain (2010) & \multicolumn{5}{l}{ Italy (2010 and 2014) } \\
\hline Law & $21 \%$ & Humanities & $24,6 \%$ & $18.4 \%$ \\
Tourism & $19.4 \%$ & Law & $23.2 \%$ & $24.2 \%$ \\
Psychology & $8.4 \%$ & Politics and sociology & $20.9 \%$ & $29.5 \%$ \\
History & $7.7 \%$ & Economics and Statistics & $10 \%$ & $3.1 \%$ \\
Business admin. and management & $6.5 \%$ & Agricultural science & $5.7 \%$ & $4.8 \%$ \\
Social education & $6.3 \%$ & Engineering & $4.2 \%$ & $3.6 \%$ \\
Others & $30.7 \%$ & Others & $7.2 \%$ & $16.4 \%$ \\
\hline
\end{tabular}

Sources: www.giustizia.it for Italy; Gutiérrez Brito et al. (2010) for Spain 
and trained to maintain secure workstations and internet connections. In addition, some studies (Bardisa Ruiz et al., 2003; Vázquez Cano, 2013) identified serious weaknesses: primarily, a frequent total ban of electronic contacts between prisoner and teacher; at the same time, a strong limitation (in terms of time and contents) in accessing the computers, Internet and even ALF itself, to take advantage of interactive learning methods and to carry out the homework. Often, as a result, only the educators have access to the platform and they download the teaching materials, while the inmate experiences the online interaction exclusively as a bureaucratic channel.

\section{CONCLUSIONS}

In the interpretation of the reasons leading the prisoners to the decision to pursue university studies, the benefits provided for by law in Italy and in Spain often take on a certain importance. However, the appeal to interests and environments other than prison carries weight without doubt into a 'dynamic of awakening' that 'has to be harnessed so that it does not turn into frustration' (Margara in Migliori, 2004, p. 17). The theme of the learning experience as discontinuity, rupture and generative opportunity emerges once again and - on the flip side - so does the idea of the continuity of the intervention, with a strategy of accompaniment during postdetention, which is currently the most significant absent factor.

Concerning the reported evidence, the advantages and limitations of the two national models - the Spanish one, that could be called centripetal, and the Italian one, that can be defined as territorial - are summarised below, through a SWOT analysis grid (Table 4).

The two models of university education in Italian and Spanish prisons, dynamically adapting to the changes experienced both by the prison and society, have responded, in some way, to the major requirements emerging from the European regulations (equalisation of education and work, integration into the public system, specific resources and support materials), albeit with accents on different, probably complementary, aspects. The Italian PUP represents a rapidly spreading model, that offers to detainees an academic education networked with the local universities. On the other hand, in Spain, UNED has developed a remarkable work, at least for the breadth of the interested people and for the length of the experience, making use of special methodologies and resources. Nevertheless, in both countries, as noted by many researchers (Coralli, 2002; Bardisa Ruiz et al., 2003; Viedma Rojas, 2013), the discretion, which is granted to the individual prisons and their management, in the authorisation of support and facilitation for higher education, appears excessively wide, such that the transformative power of the learning is still subordinated to the requirements related to security, control and punishment. The legislative requirements, as well as the moral suasion of international organisations are contributing greatly to overcoming a culture of affliction and segregation throughout Europe, but not without difficulties and delays: after all, without a serious re-balance 
Table 4. Comparative SWOT analysis between the Italian and Spanish characteristics of university education in prison

\begin{tabular}{|c|c|c|}
\hline & Spanish centripetal model & Italian territorial model \\
\hline Strengths & $\begin{array}{l}\text { Historical tradition. Complete } \\
\text { and homogeneous learning } \\
\text { offer by UNED: possibility to } \\
\text { study without being transferred. } \\
\text { Methodological specialisation. }\end{array}$ & $\begin{array}{l}\text { Specially equipped university centres } \\
\text { in prison. Facilitated contacts between } \\
\text { teachers and students and among } \\
\text { students. Activation/enhancement of } \\
\text { local resources. Horizontal integration } \\
\text { with the public education system. }\end{array}$ \\
\hline Weakness & $\begin{array}{l}\text { Poorly equipped study areas, } \\
\text { often lacking in computer } \\
\text { stations. No access to in-presence } \\
\text { learning for inmates in closed } \\
\text { prisons. Strict security policy } \\
\text { regarding Internet access. }\end{array}$ & $\begin{array}{l}\text { Prison-based facilitations in access to } \\
\text { university study (activation of PUP is } \\
\text { delegated to local initiative). Discomfort } \\
\text { in transferring to another prison. The } \\
\text { Fragmentation of learning offer. Under- } \\
\text { representation of foreigners among } \\
\text { university students. }\end{array}$ \\
\hline \multirow[t]{2}{*}{ Opportunities } & $\begin{array}{l}\text { Activation/enhancement of local } \\
\text { resources. Open prison (CIS): } \\
\text { horizontal integration with the } \\
\text { public education system and } \\
\text { external attendance. Synergy } \\
\text { with the territorial vocations. }\end{array}$ & $\begin{array}{l}\text { Synergy with the territorial vocations. } \\
\text { Improvements can come out from local } \\
\text { experimentation. Emerging interest } \\
\text { and trends: recent declaration of intent } \\
\text { between the University of Padova and } \\
\text { the Ministry of Justice; Circular of DAP } \\
\text { about Internet access (note 11). }\end{array}$ \\
\hline & \multicolumn{2}{|c|}{$\begin{array}{l}\text { Further development of distance learning through e-learning. Redoubling of } \\
\text { the learning offer through MOOCs. Strengthening of the learning support to } \\
\text { foreign detainees through web resources produced in their own countries. } \\
\text { Networking of prison libraries with other public libraries. }\end{array}$} \\
\hline Threats & $\begin{array}{l}\text { Security limitations in accessing } \\
\text { online teaching and contacting } \\
\text { UNED's teachers and tutors. } \\
\text { Centralisation and vertical } \\
\text { integration do not encourage } \\
\text { innovation and experimentation. }\end{array}$ & $\begin{array}{l}\text { To consider the university as a secondary } \\
\text { issue when, in truth: (a) it express a great } \\
\text { symbolic value as social redemption; } \\
\text { (b) Spain demonstrates that the number } \\
\text { of university students can substantially } \\
\text { grow; (c) higher education impacts } \\
\text { on placement and, consequently, on } \\
\text { recidivism. }\end{array}$ \\
\hline
\end{tabular}

No support policy in the post-detention period to facilitate the continuity of the learning careers.

in resource allocation between security and treatment, obtaining a cultural change from a custodial to an osmotic model will remain an arduous challenge.

The movement between the categories of continuity and discontinuity, as shown, could help to read the non-linear evolution of the concept and practices of imprisonment: nowadays, to some extent, they are changing the relationship 
between the correctional institutions and the outside world, increasingly osmotic, as well as the image - always imbued with complex meanings - which the prison casts on society. There is still a lot of work on this front, especially in Italy; while Spain, with the introduction of the CIS, is initiating an experience that aligns itself with the northern European open prison model. Yet also in Italy there are positive signs - which can be partly interpreted as the results of the experiments undertaken under the PUPs - such as the recent ministerial directives on the encouragement of Internet access (note 11) and on the promotion of an open cell regime (Circular of DAP n. PU-0251644, issued on 13.7.2013, regarding guidelines for dynamic surveillance).

\section{NOTES}

1 The US National Center for Education Statistics (NCES) found that $73 \%$ of all undergraduate students have at least one of the characteristics listed above (Choy, 2002). However, unlike the majority of prisoners, university students in jail do not seem to come from career failure in school, as reported by Spanish (Bardisa Ruiz et al., 2003) and English sources (Champion \& Edgar, 2013).

2 Nevertheless its limits and the increasing use of alternative measures to imprisonment, prison remains still the main option for penalty in many legal systems, involving almost 1.5 millions of people around the world in accordance with the World Prison Brief (www.prisonstudies.org).

3 On a different but interrelated level of analysis, continuity and discontinuity can represent interpretive tools of prisoners' and staff's curricula, once within a horizon leading to the radical transformation of prisons, where the involved (old and new) professional cultures should engage in the search for difficult but necessary collaborations and mediations for the development of educational communities able to produce reintegration.

4 Unlike the exceptional permit (art. 30 of the OP), the permission-prize (art. 30 ter of the OP), because its pedagogical-propulsive value, can only be obtained from prisoners under execution of sentence: to present the instance, the condemned must maintain a good conduct and must not represent a risk to society. Therefore, it has a preventive function on the one hand (helping to maintain and expand the affective, cultural and work interests of the convicted) and, on the other, an incentive function, through the mechanism of rewarding.

5 The D.P.R. n. 230/2000 adds an indication, albeit bland, to guarantee the continuity of education: whenever possible, the convicts who are engaged in treatment activities (in particular work, education and vocational training) have to be excluded from the group transfers (art. 83 par. 9).

6 Regarding the origins of the PUPs and the role of volunteers, that is remarkable until today, see: Coralli (2002), Migliori (2004), Palmisano (2015).

7 On the e-learning experimental program (higher education and university) started at the CR-ICATT of Eboli, in collaboration with the University of Salerno, see: Diana (2013), Suriano (2011), Arcangeli et al. (2010). Both involved institutions have gained international experience through the European project Grundtvig 2009 "EEPP-E-Learning Education for prisoners and prisoners professionals".

8 The library must be appropriate to the cultural and professional needs of the inmates, moreover the LOGP admits that they can take advantage of mobile libraries, established by the Penitentiary Administration or less (art. 57).

9 In 1986, in accordance with a substantially unique model (in which only the financial participation of the signatory institutions varies), a series of agreements were stipulated between UNED and the Departament de Justicia de la Generalitat de Catalunya (which autonomously manages the prisons in Catalonia, under the R.D. n. 3482/1983), the Ministerio de Defensa (for the military prison of Alcala-Meco), the Ministerio de Asuntos Exteriores (to support the Spanish prisoners in foreign countries). 
10 The main facts of this legislative change were: the accusations of favouritism and academic irregularities by UPV in favour of ETA prisoners; the public declarations of a group of professors from UPV against the pressure from ETA on the University; the intensification and the extension of the fight against terrorism to other areas of the social network of the armed bands (Viedma Rojas, 2013, pp. 90-91).

11 The LOGP clarifies that the methodology of intervention has to be adapted to the special circumstances of the prison (art. 56 par. 2), and not vice versa, thus identifying a distance learning model that, at the present day, not only UNED but also other universities are able to offer.

12 Regarding the relationship among Italian universities, Italian prison and ICT, we report that, in 2007, an agreement was signed among the CR of Alessandria, the Department of Informatics at the University of Alessandria and the Faculty of SMFN (Mathematical, Physical and Natural Sciences) at the University of "Piemonte Orientale - Amedeo Avogadro", in order to commission the development of software to students in that prison. In addition, it is important to remark that the University of Padova, by signing a declaration of intent with the Ministry of Justice in 2013, has pledged to study the experiences, to promote the discussion and to gather proposals, in order to establish a national strategy for university within the prisons. Among the first results of the work is the elaboration of some guidelines for the signing of new agreements between prisons and universities and the national conference of Padova "I Poli universitari in carcere" (Palmisano, 2015). Finally, we have to underline that one of the latest Circulars of DAP (n. PU-0366755, issued on 02.11.2015) recognizes the importance of new media as a tool for personal growth and as a support to complex pathways of treatment; consequently, it announces the creation of a centralized infrastructure (managed through a white-list system) to allow a significant proportion of convicts to navigate a selected group of websites and it also regulates the access to these workstations.

13 Data source: Progetto Pilota di Teledidattica "Università in carcere" (www.ristretti.it/areestudio/ cultura/scuola). Within the SUP of Lazio, the use of e-learning is not limited to the CC of Rebibbia NC: in fact, the Department of Law of the University of "Roma Tre" has announced the creation of MOOCs to be put at the disposal of regional prisons; moreover, the agreement between de Guarantor and the online University "Unitelma Sapienza" allows every convict in Lazio to freely enrol on degree programs or to take single examinations (Palmisano, 2015).

14 The Spanish CIS (Centros de Inserción Social: Social Integration Centres) were introduced by R.D. n. 190/1996.

\section{REFERENCES}

Arcangeli, B., Diana, P., Di Mieri, F., \& Suriano, G. (2010). L'e-learning in carcere: una proposta. Je-LKS, 6(1), 91-99.

Bardisa Ruiz, T., Viedma Rojas, A., \& Martín Pulido, P. (2003). Proyecto abierto de investigación: "El alumnado de la UNED interno en centros penitenciarios". UNED-IUED. Retrieved from http://portal.uned.es

Callejo, J., \& Ramón Bautista, J. (2003). Virtuales demandas sobre la virtualización de la enseñanza universitaria a distancia. RIED, 6(2), 77-93.

Champion, N., \& Edgar, K. (2013). Through the gateway: How computers can transform rehabilitation. London: Prison Reform Trust.

Choy, S. (2002). Nontraditional undergraduates. Washington, DC: U.S. Department of Education, National Center for Education Statistics.

Coralli, M. (2002). L'istruzione in carcere: aspetti giuridici e sociologici: L'altro diritto. Centro di documentazione su carcere, devianza e marginalità. Retrieved from http://www.altrodiritto.unifi.it/ ricerche/misure/coralli

Costelloe, A., Langelid, T., \& Wilson, A. (2012). Survey on prison education and training in Europefinal report. Birmingham: GHK - European Commission.

Czerwinski, T., König, E., \& Zaichenko, T. (Eds.). (2014). Youth and adult education in prisons. Experiences from Central Asia, South America, North Africa and Europe: IPE - International Perspectives in Adult Education 69 (pp. 72-80). Retrieved from http://www.dvv-international.de/en/materials 


\section{G. PILLERA}

Diana, P. (2013). L'e-learning in carcere. Esperienze, riflessioni, proposte. Cambio III, 6, 261-271.

Hawley, J., Murphy, I., \& Souto-Otero, M. (2013). Prison education and training in Europe: Current state-of-play and challenges. Birmingham: GHK - European Commission.

Garante delle persone sottoposte a misure restrittive della libertà personale. (2013). Relazione attività anno 2013. Retrieved from http://www.garantedetenutilazio.it

Gutiérrez Brito, J., Viedma Rojas, A., \& Callejo Gallego, J. (2010). Estudios superiores en la educación penitenciaria española: un análisis empírico a partir de los actores. Revista de Educación, 353, 443-468.

Migliori, S. (2004). Lo studio e la pena. L'Università di Firenze nel carcere di Prato: rapporto triennale 2000-2003. Firenze: Firenze University Press.

Ministerio del Interior. (2014). Anuario Estadístico del Ministerio del Interior 2013. Bilbao: Ministerio del Interior. Retrieved from http://publicacionesoficiales.boe.es

Palmisano, R. (2015). Istruzione universitaria nelle strutture penitenziarie - Tema per Stati Generali dell'Esecuzione Penale - Tavolo 9. DAP - Ufficio Studi Ricerche Legislazione e Rapporti Internazionali. Retrieved from http://www.giustizia.it

Pastore, G. (2015). Formazione e processi di inclusione sociale: il caso dei Poli universitari penitenziari. In M. A. Toscano \& A. Cirillo (Eds.), Xeni: Nuove sfide per l'integrazione sociale (pp. 235-245). Milano: Franco Angeli.

Pillera, G. (2015, November 18-20). E-literacy and access to Internet as inmate's right: European ICT frameworks in correctional education. ICERI2015 8th annual International Conference of Education, Research and Innovation, Seville, Spain.

Pillera, G., \& González Monteagudo, J. (2016). L'educatore penitenziario come tutor ed orientatore nelle carceri italiane e spagnole. In R. Biagioli (Ed.), Il tutorato nei contesti formative (pp. 69-92). Pisa: ETS.

SGIP. (2014). El Sistema Penitenciario Español. Bilbao: Ministerio del Interior - Secretaria General Técnica. Retrieved from http://publicacionesoficiales.boe.es

Suriano, G. (2011). E-learning in carcere: leva per il programma rieducativo trattamentale e per l'inserimento sociale dei detenuti ed ex detenuti. In T. Minerva \& L. Colazzo (Eds.), Connessi! Scenari di Innovazione nella Formazione e nella Comunicazione (pp. 821-830). Milano: Ledizioni.

Vázquez Cano, E. (2013). Expectativas, obstáculos y hábitos de estudio de los internos que cursan enseñanzas universitarias en la UNED. Un estudio de caso: centro penitenciario Madrid VII. Revista de Educación, 360(1), 162-188.

Viedma Rojas, A. (2013). Universitarios en prisión. Experiencias y apariencias de sentido en el espacio penitenciario (tesis doctoral). UNED, Madrid.

\section{Giuseppe Pillera}

University of Catania

Italy 